\title{
Analytical overview of dairy industry in the Poltava region, Ukraine
}

\author{
Anna Gereles \\ Poltava State Agrarian Academy, Training and Research Institute of Economics and Business, \\ Faculty of Economics and Management, Department of Business Administration and Law, Poltava \\ anna.sunny.gereles@gmail.com
}

\begin{abstract}
SUMMARY
The author presents essential characteristics of the state and place of Poltava region in it. The study aims at identification and description of latest trends in Ukraine's and Poltava's dairy industry. The author stresses an important place of the dairy industry in the agriculture of Ukraine, and particularly in the Poltava region. This article also presents the information of main indicators of dairy industry of Ukraine in the comparison with other countries of the World. It describe sources of forming the main agricultural products and directions of their use for the calendar year, data on per capita consumption of main dairy products in Ukraine and the Poltava Region and per capita average daily consumption of basic micro- and macro elements in foods. The study contains basic indicators which characterize the social and economic state of agriculture in Ukraine and its regions for 1990-2012. There are also the data of gross production and main kinds of dairy products per capita and as well as some indicators of livestock's productivity and so on.

The goal of the article is to describe the complex evaluation of the achieved level of milk production, consumption of milk and dairy products in Ukraine and the Poltava Region, to show the specifics of the national dairy cattle breeding, identifying the main challenges in it.

Keywords: Poltava region, dairy industry, number of cattle, dairy cattle farming, dairy products, milk

\section{ÖSSZEFOGLALÁS}

Jelen tanulmányban a szerzö Poltava régió helyét és szerepét mutatja be Ukrajnán belül. A tanulmány célkitüzése elsősorban a tejágazat helyzetének bemutatása Ukrajnában, illetve azon belül Poltava régióban. A szerzö a tejágazat meghatározó szerepét hangsúlyozza az ukrán és különösen Poltava mezögazdaságán belül. Jelen tanulmány a tejágazatot jellemzö legföbb mutatószámok tekintetében összehasonlitást tesz Ukrajna és a világ más országai között. A cikk bemutatja a legfontosabb mezögazdasági termékek elöállitásához szükséges forrásokat és azok felhasználásának módjait adott naptári évben, kitér továbbá a legfontosabb tejtermékek egy före esö fogyasztására Ukrajnában, valamint Poltava régióban, emellett ismerteti az alapvetö mikro- és makroelemek napi átlagos egy före jutó fogyasztását is. A tanulmány Ukrajna és régiói mezögazdaságának társadalmi és gazdasági helyzetét leiró alapvetö indikátorokat mutatja be az 1990-2012 közötti idöszakra vonatkozóan.

Jelen tanulmány célja az Ukrajnát, illetve Poltava régiót jellemzö tejtermelés valamint tej-és tejtermékfogyasztás átfogó áttekintése, rámutatva a tejelö szarvasmarhatartás nemzeti sajátosságaira és kihívásaira.
\end{abstract}

Kulcsszavak: Poltava régió, tejágazat, szarvasmarha állomány, tejelö szarvasmarhatartás, tejtermékek, tej

\section{INTRODUCTION}

Poltava Region is one of the leading and well-developed from the 25 Ukrainian regions, which is situated at the left bank of Dnepr in its middle flow and occupies the territory of 28.8 thousand square $\mathrm{km}$ (5\% of Ukraine territory). The region extent from north to south is 213.5 $\mathrm{km}$ and from east to west $-245 \mathrm{~km}$. Poltava Region borders on Chernihiv, Sumy, Kharkiv, Dnipropetrovsk, Kirovograd, Cherkassy and Kyiv regions. The region has advantageous geographical position, plane relief, temperate continental climate, considerable reserves of mineral resources.

Situated in Dnepr middle flow, modern Poltava Region (in economic structure) is the industrially-agricultural region famous for the output of iron-ore, gas and oil, producer of freight cars, railway cars, diamond instrument and other products of car building, with powerful agriculturally-industrial complex, advanced light, food and processing industries. In the gross production of industry and agriculture the share of industry is almost $60 \%$. Infrastructure of region is characterised by the developed net of railways and motorways. There is an airport which is intended for the reception and maintenance of passenger and transport airplanes. The industry of Poltava
Region is presented by more than 350 of big enterprises. The leading fields are fuel industry, ferrous metallurgy, car building, light and food industries, which provide more than $80 \%$ of industrial products manufacturing.

Plain relief, fertile black earth, favourable climate create necessary prerequisites for the development of the agriculture. Earth resources of region compose 2.8 mln hectares among which $1.62 \mathrm{mln}$ are the agricultural areas. The leading fields of food industry are: dairy and meat, sugar, baking, confectionery, fruit and vegetable, food-canning, spirit and alcoholic beverage, brewing, oil-mill, production of non-alcoholic drinks.

As for the dairy industry, it takes an important place in the agriculture of Ukraine, as well as the Poltava Region, as it provides the population of vital food products, many of which are strategic in the export potential. According to United Nations Food and Agriculture Organization (FAO), global dairy market has one of the most upward growth potential the total food market. The key growth drivers are demands from Asian countries, Russia, Ukraine and Belarus. Ukraine belongs to the TOP 20 global producers of milk. According to results 2011, $11.1 \mathrm{mln}$ tons of milk were produced in the country. The dairy industry of Ukraine totals over 450 enterprises, but recently only about 250 dairy plants/enterprises really process 
large volumes of milk (over $6 \mathrm{mln}$ tons). Moreover Ukraine is a netexporter of dairy products, supplying annually 1 million tons thereof in terms of milk. Naturally, Ukrainian dairy producers are looking at world prices in order to stay competitive on the global market.

As for Poltava Region in 2012 it ranks the second one in milk production (6.2\%) and in 2013 - the first one. Poltava has one of the largest breeding bases in Ukraine (42 companies engaged in dairy and meat cattle and 3). The biggest number of cattle is concentrated in Gadyachsky, Globynskyy, Khorolsky, Shyshatskiy counties of the Poltava Region. The dynamics of milk production is charactarised with positively increasing during last five years that means positive developments in this area. That's why the Poltava region could be competitive at the Ukrainian dairy market, as well as at the European and World markets.

\section{MATERIAL AND METHODS}

The investigations on the effective development of milk production, dairy industry in general and existing organizational and economic relations were made by many Ukrainian and foreign scientists and economists, including: Andriychuk (2002), Butko (2010), Kobets (2007), Malik (2002), M. Ryzhkova (2008), Sabluk (2002), Tsymbal (2010), Vasylchak (2005) and others. However, according to the last years' features and trends in the dairy industry, some approaches proposed by these authors require the deepening and adaptation to the modern realities in the specific context of the improving competitiveness in the domestic and the foreign dairy markets.

Information database for compilation of food resources' balances is data derived from state statistical observations on activity of enterprises and organizations in the field of agriculture, processing industry, trade as well as data of sample surveys on households' living conditions and their agricultural activity, information of customs statistics and other official sources which characterize the forming of food resources and their usage. For our research we tried to use the latest official statistic data from State Statistic Service of Ukraine and Department of Agricultural Statistics and Environment in the Poltava Region for more up-to-date comparison with the World and European databases. But in some cases the last statistics that we could use due our research purposes is two or three years old, because of the regional difference.

Consumption of dairy products in kilograms for a year is calculated as the consumption fund of respective products per capita for average annual population of the Poltava Region. Consumption fund includes quantity of products used on private consumption in any kinds and consists from products of report year's production, imported, previous years' production in the form of stocks consumed.

This article contains information about the number of cows, indicators of their productivity, animal production, fodder expenditures and grouping of agricultural enterprises by main indicators, which characterize development of animal production. Livestock number is calculated on the basis of annual enumeration as of January 1. It includes respective livestock species of all sex-age groups.
Milk production is the actual quantity of milk yield from cows, sheep and goats irrespective of whether it was sold or partly used for domestic needs for sucking either by calves or by piglets. Milk sucked by calves during the growing up period is not included in the milk production.

Average annual milk yield per cow is based on the number of cows at the beginning of the year, regardless of the fact whether a cow gave milk during a reference year. In agricultural enterprises milk yield per cow is based on the total number of cows, excluding cows kept for feeding, cows of meat herd as well as cows used for sucking purpose and for feeding the group of calves if these cows were not milked.

Milk production per capita is estimated by dividing the production volume by the average annual number of present population. Present population number in Kyiv Region includes population in Kyiv, and present population number in Autonomous Republic of Crimea includes present population in Sevastopol city.

\section{RESULTS}

Ukraine belongs to the TOP 20 global producers of milk (Table 1). Despite its position, the Ukrainian dairy industry is suffering from a permanent deficit of raw milk supplied for processing. In average, in 2007-2011 over half of the produced raw milk did not reach the processors. One of the reasons behind this lasting trend is that the structure of initial production of raw milk is dominated by households (having a share of $80 \%$ ).

It was important to make the comparison of milk production in Ukraine with world's top 10 countriesmilk producers and with some closest neighbor countries from the Commonwealth of Independent States (CIS) simultaneously (Table 1) due to similar climate and environmental conditions, technological level of dairy production and common dairy markets.

Ukrainian dairy export isn't diversified enough. Most dairy products get to near-abroad, especially to Russia. Having some priorities our neighbor sometimes sets limitations or blocks imports of Ukrainian dairy products. Such steps influence negatively both dairy processors and producers. As a result, there is a need to look for new markets, where Ukrainian operators could distribute their products.

Forecasts of Food and Agriculture Organization (FAO) and some other analytical organizations affirms that in 2015-2020 world milk production will raise to 65 million tones. India will provide half of this growth, China - about $20 \%$, milk production will rise up to 8 million tons in the USA and to 7 million tones in EU. Even such 'low' growth troubles producers and processors in Europe, while debates over coming changes on dairy market continue.

Milk production in Ukraine is expected to grow moderately in 2013 and 2014. The overall increase will be close to one percent. The number of cows will continue to decline while per cow yield will be growing in both household sector and industrial farms. Efficiency increase is especially evident among industrial enterprises, which decreased the cow inventory by $1.3 \%$, but managed to increase total raw milk yield by $1.6 \%$. 
Milk production in Ukraine in the comparison with other countries of the World (1990-2011)

\begin{tabular}{|c|c|c|c|c|c|c|c|}
\hline Milk production (millions of tons) & 1990 & 1995 & 2000 & 2005 & 2009 & 2010 & 2011 \\
\hline Ukraine & 24.5 & 17.3 & 12.7 & 13.7 & 11.6 & 11.2 & 11.1 \\
\hline World total & 542.5 & 539.1 & 579.1 & 629.1 & 702.2 & 720.9 & 727.1 \\
\hline Argentina & 6.3 & 8.8 & 10.1 & 9.9 & 10.4 & 10.5 & 10.5 \\
\hline Belarus & $\cdots$ & 5.1 & 4.5 & 5.7 & 6.6 & 6.6 & 6.5 \\
\hline Brazil & 15.1 & 17.1 & 20.5 & 25.5 & 30.2 & 31.8 & 32.2 \\
\hline United Kingdom & 15.3 & 14.8 & 14.5 & 14.6 & 13.2 & 14.0 & 14.2 \\
\hline Italy & 12.0 & 12.3 & 13.3 & 11.6 & 11.3 & 11.3 & 11.1 \\
\hline Kazakhstan & $\ldots$ & 4.6 & 3.7 & 4.7 & 5.3 & 5.4 & 5.2 \\
\hline China & 7.0 & 9.5 & 12.4 & 28.7 & 40.4 & 41.2 & 41.8 \\
\hline Netherlands & 11.2 & 11.3 & 11.2 & 10.5 & 11.5 & 11.6 & 11.8 \\
\hline Germany & 31.3 & 28.6 & 28.4 & 27.6 & 29.2 & 29.7 & 30.3 \\
\hline Poland & 15.8 & 11.6 & 11.9 & 12.4 & 12.5 & 12.3 & 12.4 \\
\hline Russian Federation & $\ldots$ & 39.3 & 32.3 & 30.9 & 32.6 & 32.1 & 31.6 \\
\hline USA & 67.0 & 70.4 & 76.0 & 80.3 & 85.9 & 87.5 & 89.0 \\
\hline France & 26.8 & 26.1 & 25.7 & 26.1 & 23.5 & 24.2 & 25.3 \\
\hline Share of Ukraine in World total (\%) & 4.5 & 3.2 & 2.2 & 2.2 & 1.7 & 1.6 & 1.5 \\
\hline
\end{tabular}

Note: ... - data is absent, Source: State Statistic Service of Ukraine

Cheese remains Ukraine's major exportable dairy sector commodity with over 87 percent of all exports going to Russian Federation. Dependence of the cheese trade from trade regime in Russia is very significant. During 2012-2013 there were multiple trade disruptions for Ukrainian cheese producers as Russian controlling authorities stopped exports. The biggest problem appeared in February of 2012 when Rospotrebnadzor banned imports from six major Ukrainian producers: Pyriatynsky Cheese plant, Ahtyrka Cheese Plant, Dubnomoloko, Prometei, Gadiachsyr and Lozovsky Daory Plant. The allegations were disconfirmed in April with limited cheese supplies renewed in May. Full scale exports continued to be restrained till August of 2012 with additional control imposed till April of 2013. According to Russian authorities additional 1.260 samples were taken during 2012 and early 2013.
The list of approved facilities was changing rapidly throughout last year. In August 2013 Rosselkhoznadzor discovered antibiotics in cheese produced by two Ukrainian plants: Prometey and Mensky Syr. This triggered additional import controls of each cheese batch produced at these two plants. In October 2013, Molis Company returned to the list of approved suppliers. Currently the list includes 17 Ukrainian producers approved for export to Russia and changes are possible at any moment.

As for Poltava Region, this year it received a first place in the country in milk production (Figure 1). In 2012 in the livestock industry of the Poltava Region only the milk production was profitable (the profitability was $28.7 \%)$.

Figure 1: Number of cattle (thousands of heads) and milk yields (thousands of tons) by regions of Ukraine (2012)

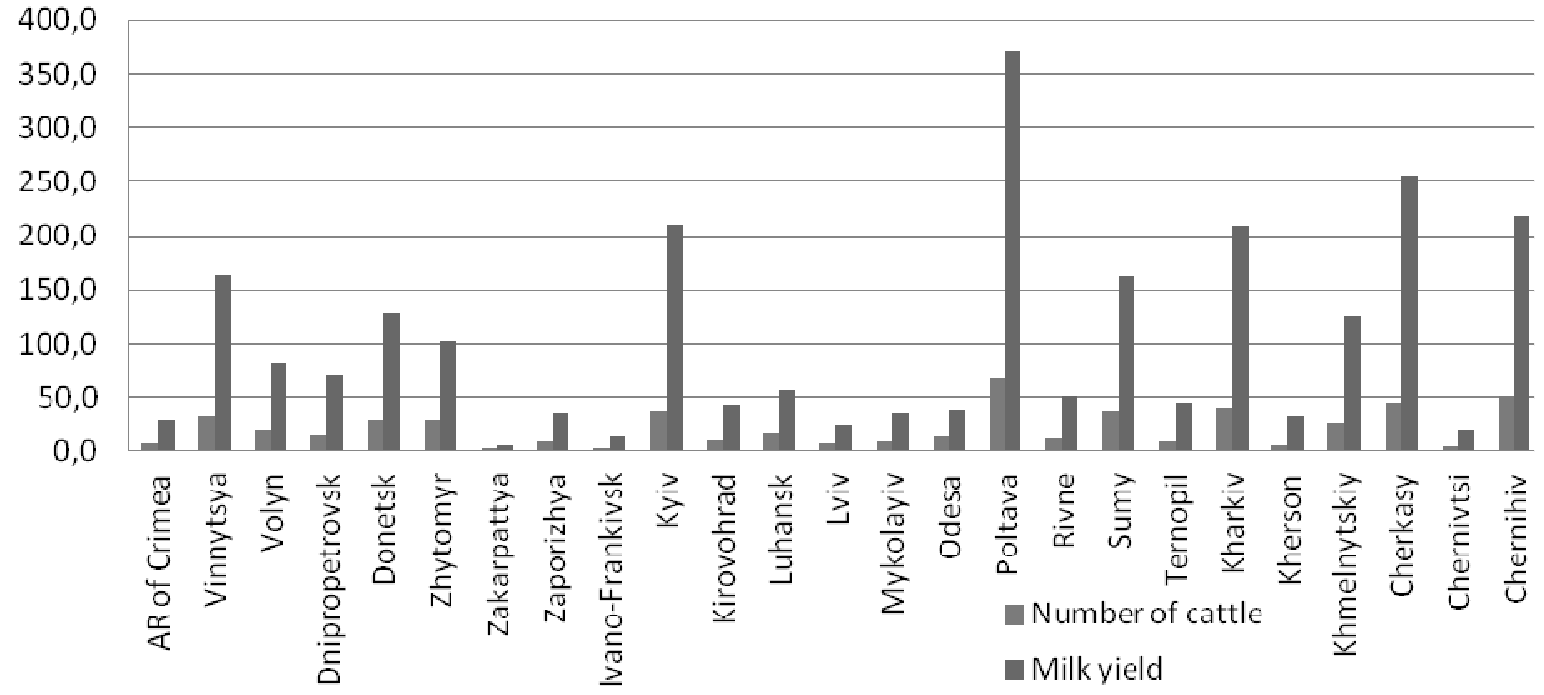

Source: State Statistic Service of Ukraine 
In 2011, the output of livestock products compared to 2010 increased by $3.8 \%$, including agricultural enterprises $-3.5 \%$ of households $-4.0 \%$. In 2011 , farms of all categories produced 725.4 thousand tons
(3.4\% more) of milk that shows us the increased milk production by $4.1 \%$. Households in 2011 produced $56.6 \%(56.9 \%)$ of total milk (Figure 2$)$.

Figure 2: Milk Production by regions in 2012

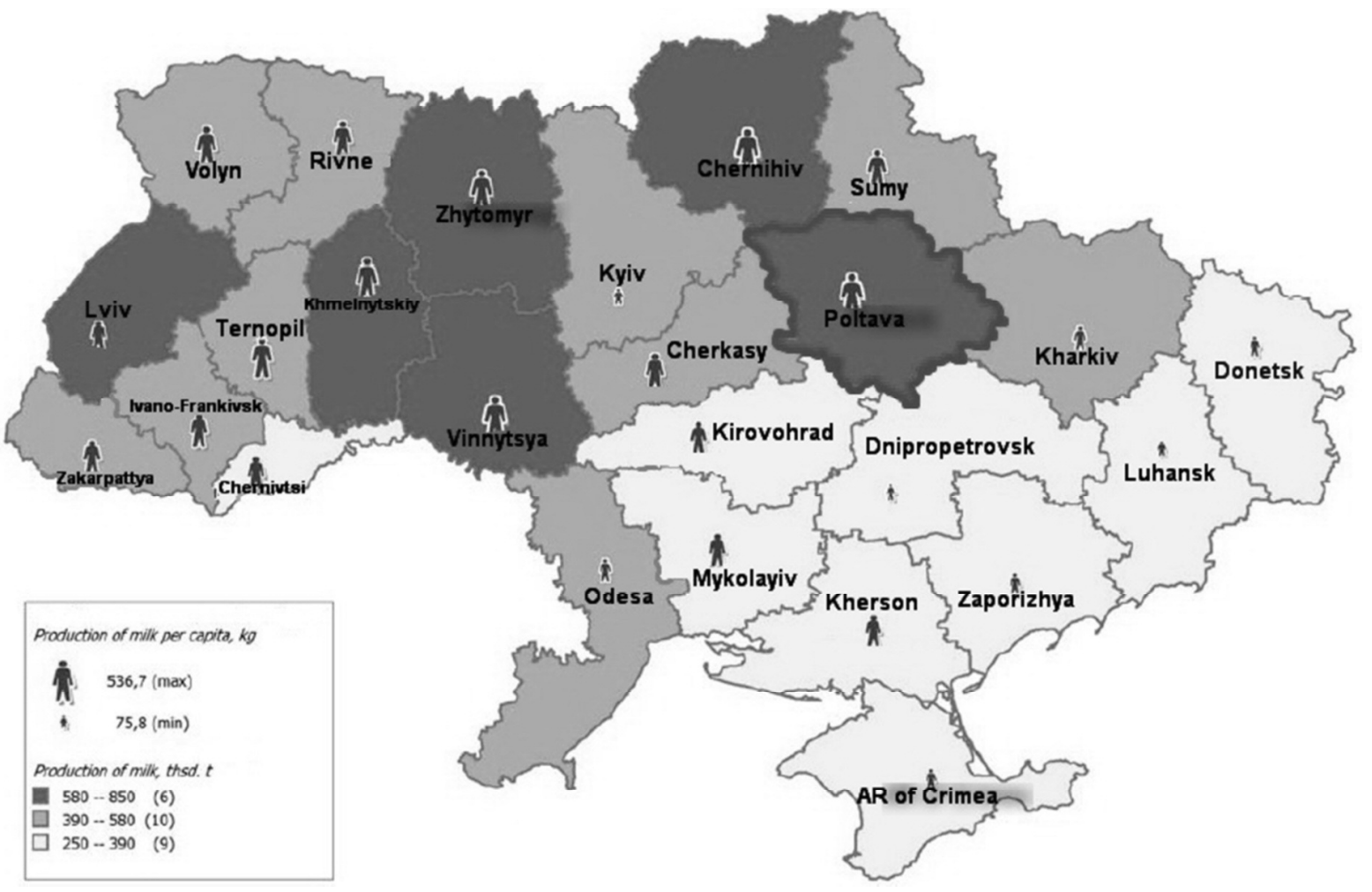

Source: State Statistic Service of Ukraine

In 2011, the consumption of milk and dairy products in the Poltava Region was 329.8 thousand tons $(100.5 \%)$. The statistics shows that this consumption on average per person was higher than the average for Ukraine - $17.6 \mathrm{~kg}(8.6 \%)$

Regarding the performance of livestock in 2011 compared with 2010 agricultural enterprises increased the average annual milk yield per cow by $3.3 \%$ (was $4787 \mathrm{~kg})$.

Compared to January 1, 2011 farms increased cattle population by $3.3 \%$. Following the grouping farms by the number of livestock as at 1 January $201237.5 \%$ of enterprises had 299 head of cattle, $15.5 \%$ - from 300 to 499 heads, $20.2 \%$ - from 500 to 999 heads $17.4 \%$ from 1000 to 1999 heads, $9.4 \%$ - more than 1999 goals, including a herd of cows to 199 the number of heads held $45.8 \%$ of the enterprises from 200 to 399 heads $-24.1 \%$, from 400 to 999 heads $-23.2 \%$, more than 999 heads only $6.9 \%$ of enterprises.

Poltava Region has one of the largest breeding bases in Ukraine. 42 companies engaged in dairy cattle breeding in the region. Number of cattle in all categories of the most concentrated in Gadyachsky, Hlobynskyy, Khorolsky Shishatskiy counties of the Poltava region. But now the number of livestock in the Poltava region drastically reduced (Table 2). Thus, the number of cattle in all categories decreased during 1980-2012 in more than five times.
Table 2.

Number of cattle in the Poltava region (1980-2012)

\begin{tabular}{lcc}
\hline \multirow{2}{*}{ Years } & \multicolumn{2}{c}{ Number of cattle (thousands of heads) } \\
\cline { 2 - 3 } & Total & Including cows \\
\hline 1980 & 25367.6 & 9271.1 \\
1985 & 26638.0 & 8851.4 \\
1990 & 24623.4 & 8378.2 \\
1995 & 17557.3 & 7531.3 \\
2000 & 9423.7 & 4958.3 \\
2005 & 6514.1 & 3635.1 \\
2006 & 6175.4 & 3346.7 \\
2007 & 5490.9 & 3095.9 \\
2008 & 5079.0 & 2856.3 \\
2009 & 4826.7 & 2736.5 \\
2010 & 4494.4 & 2631.2 \\
2011 & 4425.8 & 2582.2 \\
2012 & 4645.9 & 2554.3 \\
\hline
\end{tabular}

Source: Department of Agricultural Statistics and Environment in the Poltava Region

Despite the constant reproach to the quality of raw milk produced in households the state urgently needs to reform the dairy industry - for such long time small farms are a major producer of milk in Ukraine. In 2012 more than $80 \%$ of the milk was produced by this category. However, there are some differences within Ukraine. 
Thus, in the central and northeastern regions such as Poltava, Cherkasy, Kyiv, Chernihiv, Sumy, and some Eastern regions, their share is below the average for Ukraine - not more than 70\% in the structure of milk production. While the Western and South-Western regions are characterized by a significant proportion of households and sometimes it reaches $98 \%$. Thanks households for at least the last 15 years regions were satisfied domestic demand of milk and dairy products.

Part of the increase in animal number in the households can be attributed to state support programs initiated in 2012 that targeted households. The program covers registered young bovine animals (registration sometimes is not the case in the households) that were born in households and not slaughtered. For 3-5 month old it is UAH 250 (\$31.25) per head, for 6-8 months old cattle, UAH 500 (\$62.50) were allocated, and for 9-11 month olds, the amount is UAH 750 (\$93.75). In the future the state budget support program will be targeting longevity of young animals. The sum would be equal to UAH 250 (\$31.25) per head every three months until the animal reaches 11 months of age. Although the support sum is relatively small, money distribution is often delayed and access to it is not straightforward the program may have had a limited impact.

Insignificant industrial milk production in the Poltava Region leaves dairy processors no choice but to procure milk from households. Many processors enter into cooperation agreements with individual suppliers or with village communities in an attempt to increase quality and decrease seasonality. Processors often offer long-term contracts with more attractive pricing, supply some villages with modern refrigeration systems and milk tanks. Many run educational programs on sanitary rules. Milk from industrial farms continues to be the most desirable by the processors due to consistent quality.
This milk allows for production of high-margin whole dairy products and cheese.

For example cooperative "Molochnyk-Sushky" in the Kozelshchyn County, that delivers $500 \mathrm{~kg}$ of milk daily, gradually increasing the productivity of milk collection to 2 tons per day. Milk is supplied to Kremenchuk dairy plant, which after the integration of Danone and Unimilk became part of the merged Danone-Unimilk company. At present, eight families, the owners of private farms, have already become the members of the cooperative. Total investment in the ASK "Molochnyk-Sushky" is UAH 170000. The program of the establishment of the establishment of dairy cooperatives, funded by Danone Ecosystem Fund, was launched in Ukraine in February 2010 and is supported by the International Charitable Foundation "Community Wellbeing". New equipment was installed in all cooperatives; particularly this is large-size cooling baths for milk and analyzers, allowing to provide the necessary temperature and hygienic conditions of milk storage. The main objective of the project is to improve the quality and increase the production of milk by rural population.

The project will develop multi-functional agricultural service cooperatives and in such a way provide the means and opportunities to improve the quality of lives of at least 20 rural communities in Kherson, Zaporizhzhia, Kirovograd, Dnipropetrovsk, Poltava regions and AR of Crimea. One of the main benefits of membership in the cooperative is the members' ability to receive pedigree dairy cows (heifers) for free, and also new ways of selling products at prices favourable for the villagers. Those members of cooperatives who receive animals undertake to adhere to the principle of Gift Giving: raise heifers and give them to the next family.

\section{REFERENCES}

Andriichuk, V. (2002): Economics of agricultural enterprises. Kiev. KNEU. 624.

Association "Ukrainian Agribusiness Club" (2011): Doing Agribusiness in Ukraine. Kiev. 4: 60 .

Butko, M. (2010): The agro-industrial integration as a way to enhance the agricultural production. Agrosvit. 3: 10-13.

Kobets, E. (2007): The historic aspects of the integration, its forms and directions. The State and Regions. The Series: Economics and Business. 2: 129-133.

Nivievskyi, O.-Ilienko, I.-Ryzhkova, M. (2008): Dairy supply chain in Ukraine: bottlenecks and directions for development. Poster Paper presented at IAMO Forum 2008. Halle (Saale): LeibnizInstitut für Agrarentwicklung in Mittel- und Osteuropa (IAMO). 130
Sabluk, P.-Malik, M.-Valentines, V. (2002): The inter-relationships' formation: problems of the theory and methodology. Kiev. IAE. 294.

Statistic Yearbook “Agriculture of the Poltava Region 2011" (2012) Poltava: Department of Agricultural Statistics and Environment in the Poltava Region. 268. http://www.poltavastat.gov.ua/

Statistic Yearbook “Agriculture of Ukraine 2010” (2011): Kyiv: State Statistic Service of Ukraine. 374. http://www.ukrstat.gov.ua/

Statistic Yearbook "Agriculture of Ukraine 2011" (2012): Kyiv: State Statistic Service of Ukraine. 406. http://www.ukrstat.gov.ua/

Statistic Yearbook “Agriculture of Ukraine 2012” (2013): Kyiv: State Statistic Service of Ukraine. 392. http://www.ukrstat.gov.ua/

Tsymbal, V. (2010): In a single impulse: agricultural holdings. AgroPerspective. 2: 20-27.

Vasylchak, S. (2005): The formation and development of the regional milk and milk products market. Lviv. Ukrainian technology. 40. 
